\title{
ПРАВОВІ АСПЕКТИ СТЯГНЕННЯ ПОДАТКОВОГО БОРГУ: АНАЛІЗ НАЦІОНАЛЬНОГО ТА ЗАРУБІЖНОГО ЗАКОНОДАВСТВА
}

\author{
Лихолат Я. А., Мацелик Т. О.
}

у статті визначено основні проблемні аспекти
законодавства в контексті стягнення податкового
боргу, з огляду на особливості національного право-
творення та специфіку соціально-економічних проце-
сів на сучасному етапі розвитку. «Податковий борг»
$\epsilon$ не тільки економічною, але і правовою категорією,
яка відображає сутність його взаємопов'язаних скла-
дових частин: узгодженого грошового зобов'язання, штрафних санкцій та пені. Визначення податкового боргу набуло правового закріплення в податковому законодавстві, на відміну відпоняття «стягнення податкового боргу", яке перебуває тільки в науковому обігу. Окрім зазначеного, недоліками правового регулювання стягнення податкового боргу $\epsilon$ відсутність тимчасової законодавчої бази, яка спроможна регулювати податкові правовідносини в умовах карантинних обмежень. Чинники об'єктивного і суб'єктивного характеру безпосередньо впливають на динаміку податкового боргу, показник якого останніми роками $\epsilon$ досить високим. Такі тенденції свідчать про необхідність удосконалення механізму податкового адміністрування, який не може належно функціонувати без якісної правової бази й ефективних методів управління податковим боргом. Проаналізовано останні законодавчі нововведення, якими передбачаються розширення функціональних повноважень податкових органів, зокрема в частині податкового контролю та зміни в механізмі стягнення податкового боргу, які будуть дієвими за умови створення повноцінних умов для життєдіяльності платників податків. Тому дослідженням ураховано ефективність застосування закордонних інструментів у процесі примусового стягнення податкового боргу, можливість їх реалізації на національному рівні. Із цієї метою проаналізовано податкове законодавство закордонних країн та визначено відмінності податкової практики в частині реалізації податкової застави, відстрочення/розстрочення виконання податкового зобов'язання. Окрему увагу приділено механізму податкового контролю за фінансовим станом потенційного та реального податкового боржника, оскільки статистичні дані щодо списання безнадійного податкового боргу свідчать про неефективність заходів податкової політики. Тому враховано закордонний досвід списання безнадійного податкового боргу, умов

(с) Лихолат Я. А., Мацелик Т. О., 2020 його визнання, а також реалізації попереджувальних заходів для запобігання його виникненню.

Ключові слова: правове регулювання, податковий борг, способи стягнення податкового боргу, податкова застава, безнадійний податковий борг.

Lykholat Ya. A., Matselik T. 0 . Legal aspects of tax debt collection: analysis of national and foreign legislation

The article identifies the main problematic aspects of the legislation in the context of tax debt collection, taking into account the peculiarities of national law-making and the specifics of socio-economic processes at the present stage of development. Tax debt is not only an economic but also a legal category, which reflects the essence of its interrelated components: a concerted monetary obligation, and penalties. The definition of "tax debt" is legally enshrined in tax law, in contrast to the "collection of tax debt", which is only in scientific circulation. In addition to the above, the shortcomings of the legal regulation of tax debt collection are the lack of a temporary legal framework that can regulate tax relations under quarantine restrictions. Factors of both objective and subjective nature directly affect the dynamics of tax debt, which has been quite high in recent years. Such trends indicate the need to improve the mechanism of tax administration, which can not function properly without a quality legal framework and effective methods of tax debt management. The latest legislative innovations are analyzed, which provide for the expansion of the functional powers of tax authorities, in particular in terms of tax control and changes in the mechanism of tax debt collection, which will be effective provided full conditions for taxpayers. Therefore, the study takes into account the effectiveness of foreign instruments in the process of forced collection of tax debt and the possibility of their implementation at the national level. To this end, the tax legislation of foreign countries is analyzed and the differences of tax practice in terms of the sale of tax collateral, deferral / installment of tax liability. Particular attention is paid to the mechanism of tax control over the financial condition of potential and actual tax debtors, as statistics on the write-off of bad tax debt indicate the ineffectiveness of tax policy measures. Therefore, foreign experience in writing off bad tax debt and the conditions of its recognition, as well as the implementation of preventive measures to avoid cases of its occurrence, is taken into account.

Key words: legal regulation, tax debt, methods of tax debt collection, tax lien, bad tax debt. 
Постановка проблеми та ії актуальність. На сучасному етапі функціонування податкової системи необхідно враховувати не тільки інтереси держави в частині формування дохідної частини бюджету, а також інтереси кожного платника податків, створювати оптимальні умови виконання податкових зобов'язань. Нині важливою проблемою правового та соціально-економічного характеру $\epsilon$ виникнення податкового боргу, що зумовлене порушенням балансу публічних та приватних інтересів. Вирішити вищезазначену проблему можна тільки шляхом усунення недоліків чинної правової бази, використання на практиці тільки ефективних способів та методів управління податковим боргом.

Аналіз останніх досліджень i публікацій. Основні проблемні аспекти правового регулювання стягнення податкового боргу розкриті в наукових працях таких вітчизняних учених: Д.В. Цвірюк, А.Р. Олійник, А.М. Серебрянського, О.М. Смірнової, М.В. Стадник, М.В. Трубіної. Проте сучасні реалії податкових відносин потребують нового наукового дослідження.

Мета статті - зробити аналіз вітчизняного та закордонного законодавства, що регулює функціонування інституту стягнення податкового боргу, дослідити практичні аспекти його реалізації, зазначити проблеми правозастосування, можливі шляхи їх вирішення.

Виклад основного матеріалу. Тенденції функціонування сучасної податкової системи свідчать про наявність деструктивних явищ, як-от ненадходження податкових та інших платежів до відповідних бюджетів, що зумовлюють виникнення податкового боргу. Як свідчать статистичні дані, на початок 2020 р. загальна сума податкового боргу становила понад 124 млрд грн, а вже станом на 1 вересня 2020 р. його рівень зріс майже на 500 млн грн, що вказує на неефективність податкової політики щодо управління податковим боргом. Рівень та динаміка поширення податкового боргу в закордонних країнах безпосередньо залежать від ефективності реалізації своєрідних моделей та підходів у контексті запобігання, погашення та примусового стягнення податкового боргу. Для України вважається корисним визначення перспективних методів та способів управління податковим боргом, можливість їх адаптації на національному рівні з урахуванням особливостей соціально-економічного розвитку та державно-правових процесів.

Натепер порядок стягнення податкового боргу регулюється Податковим кодексом України та підзаконними нормативно-правовими актами, які забезпечуються реалізацію окремих процесуальних аспектів.

У податковому законодавстві визначено сутність податкового боргу як суми узгодженого грошового зобов'язання, не сплаченого платником податків у встановлений цим Кодексом строк, та непогашеної пені, нарахованої в порядку, визначеному цим Кодексом [1].

Д.В. Цвірюк пропонує на законодавчому рівні закріпити стягнення податкового боргу як учинення заходів примусу щодо зменшення податкового боргу уповноваженими на те органами (відповідне право мають виключно органи контролю в межах своїх повноважень) [2, с. 32]. Отже, автор вказує на дефініцію понять “стягнення" та «погашення», тому під останнім необхідно розуміти виконання платником податків зобов'язань зі сплати податкового боргу самостійно.

3 метою оптимізації діяльності органів контролю та забезпечення належного правозастосування положень податкового законодавства в контексті стягнення податкового боргу на законодавчому рівні було ухвалено Закон України «Про внесення змін до Податкового кодексу України щодо вдосконалення адміністрування податків, усунення технічних та логічних неузгодженостей у податковому законодавстві» від 16 січня 2020 р. № 466-ІХ, відповідно до якого:

1) розширюються повноваження органів контролю, а саме закріплюються такі права: аналізувати фінансовий стан платника податків, який має податковий борг або належить до категорії ризикових платників податків; звертатись до суду з метою погашення боргових зобов'язань коштом майна платника податків цілком або частково;

2) доповнюються правові підстави для припинення права податкової застави: органом контролю в разі підтвердження не лише повного погашення суми податкового боргу, а й повного погашення розстрочених (відстрочених) грошових зобов'язань та процентів за користування розстроченням (відстроченням); платником податків у разі згоди контролюючого органу на відчуження майна, що перебуває в податковій заставі;

3) скорочуються строки самостійного виконання податкового зобов'язання зі сплати суми податкового боргу, протягом якого не провадяться стягнення коштів та продаж майна боржника, із 60 до 30 календарних днів;

4) зменшується термін оцінки майна, що перебуває в податковій заставі, із 2 до 1 місяця, яка може проводитись на підставі договору з оцінювачем такого майна; 
5) забезпечується періодичне оприлюднення статистичних даних щодо податкового боргу суб'єктів господарювання [3].

За умови належного правозастосування передбачені нововведення здатні налагодити функціонування механізму обліку податкового боргу й удосконалити процес його стягнення.

У процесі проведення аналізу змін законодавства необхідно зазначити, що нерозглянутими залишились колізії правового регулювання щодо:

1) послідовності реалізації арешту коштів на рахунках платника податків і арешту майна та визначення конкретних умов їх застосування;

2) забезпечення вжиття заходів примусового стягнення податкової заборгованості в умовах карантинних обмежень.

3 метою налагодження партнерських відносин між контролюючим органом та платником податків законодавець закріпив положення щодо забезпечення виконання податкових зобов'язань. Отже, право податкової застави виникає у зв'язку з виникненням податкового боргу як гарантія задоволення державних інтересів коштом заставленого майна. Відповідно до рішення органу контролю, податковий керуючий організовує проведення опису майна, на яке поширюється право податкової застави, та її реєстрацію в обов'язковому порядку.

«Платник податків зберігає право користування майном, що перебуває в податковій заставі, якщо інше не передбачено законом, та може відчужувати його тільки за згодою контролюючого органу» [1]. Винятками правозастосування цього положення $\epsilon$ ненадання контролюючим органом згоди на відчуження заставленого майна протягом законодавчо визначеного строку звернення платника податків із такою вимогою або реалізація вже готової продукції. Проте в будь-якому разі отримані в результаті відчуження майна кошти мають бути спрямовані на погашення податкового боргу.

Корисним для України є досвід Республіки Грузія, законодавством якої передбачено: «якщо майно, обтяжене податковою заставою/іпотекою, буде продано або будь-яким іншим способом передано іншому власнику без скасування державою податкової застави/іпотеки, право застави/іпотеки знову поширюватиметься на нового власника вказаного майна. Будь-яке інше право застави/іпотеки нового власника буде мати меншу силу щодо того права податкової застави, яке існувало до продажу або передачі» [4, с. 182]. Запозичення такої практики дозво- лить державі повноцінно реалізувати забезпечувальну функцію податкової застави та спрямувати активи платника податків на погашення податкового боргу, оскільки як у платника податків, так і в будь-якої іншої особи фактично не буде виникати наміру щодо неправомірного розпорядження заставленим майном.

У податковому законодавстві Азербайджанської Республіки право податкової застави реалізовується на підставі договору між платником податків та контролюючим органом, уважається диспозитивним способом забезпечення, у результаті застосування якого продовжується строк виконання податкового зобов'язання.

У п. 85.10 ст. 85 Податкового кодексу Азербайджанської Республіки визначено, що «за наявності підстав строк виконання податкового зобов'язання може бути продовжений від одного до дев'яти місяців протягом податкового року. Протягом цього строку проценти платнику податків не нараховуються» [5, с. 82].

У такому разі податкова застава набуває особливостей цивільно-правового способу виконання податкових зобов'язань. Запозичення такого виду застави на національному рівні $\epsilon$ ефективним, якщо платник податків - податковий боржник не має достатньої кількості майна або суми грошових коштів для погашення всієї суми заборгованості. На відміну від розстрочення (відстрочення) сплати податкового боргу, продовження строку виконання податкового зобов'язання не передбачає застосування штрафних санкцій та пені.

«Якщо протягом місяця із дня застосування іпотеки боржник не розрахувався з бюджетом, податковий орган може самостійно здійснити продаж рухомого майна такого платника податків або передати таке стягнення до судового виконавця. Якщо попередні заходи стягнення не привели до погашення податкового боргу в повному обсязі, податковий орган має право видати наказ про продаж нерухомого майна за ціною, визначеною таким податковим органом. Якщо протягом двох місяців із дня видання такого наказу платник податків самостійно не продав нерухоме майно та не погасив податковий борг, податковий орган визначає дату проведення судового аукціону із продажу цього майна» [6]. У податковому законодавстві України не передбачений термін, протягом якого реалізується право податкової застави, окрім загального строку давності його реалізації, що становить 1095 днів. Крім цього, продаж як рухомого, так і нерухомого майна здійснюється суто шляхом проведення цільового аукціону, без 


\section{Економічна безпека держави: теорія і практика}

безпосередньої участі платника податків у цьому процесі.

Положеннями ст. 194 Податкового кодексу Республіки Молдова передбачено значний перелік способів примусового порядку виконання податкового обов'язку:

“а) стягнення грошових коштів, зокрема й в іноземній валюті, з банківських рахунків платника податків, за винятком тих, що зберігаються на кредитних і тимчасових рахунках (з накопичення фінансових коштів для формування або збільшення статутного капіталу);

b) вилучення готівкових коштів, зокрема й в іноземній валюті, у платника податків;

c) звернення стягнення на майно платника податків, крім зазначеного в п. п. а) і b);

d) звернення стягнення на дебіторську заборгованість платника податків способами, передбаченими п. п. а), b) і с)" [7].

Однак податковим органам не завжди вдається забезпечити реалізацію передбачених способів стягнення через причини об'єктивного чи суб'єктивного характеру.

Зокрема, «примусове виконання податкового зобов'язання визнається неможливим у разі, якщо:

а) ліквідована особа не має правонаступника і не має у своєму розпорядженні майна, на яке може бути звернено стягнення;

b) особа перебуває у процесі ліквідації (розпуску) або неспроможності;

с) $\epsilon$ судовий акт, що припиняє виконання рішення Державної податкової служби у справі про податкове порушення або про примусове стягнення - на період дії акта про призупинення;

d) $\epsilon$ відповідний акт судової інстанції або судового виконавця, згідно з яким стягнення недоїмки неможливо, або $є$ постанова про порушення кримінальної справи за фактом псевдопідприємництва;

е) $€$ рішення Державної податкової служби про зупинення виконання оскаржуваного рішення і проведення повторної перевірки (п. d) ч. (1) ст. 271) - на період дії акта про призупинення» [7].

В Україні фактом визнання податкового боргу юридичної особи є банкрутство такої особи, якщо вимоги органу контролю не можуть бути задоволені у зв'язку з відсутністю грошових коштів або майна юридичної особи, а також майна їі засновників або учасників відповідно до умов відповідальності.

3 метою уникнення випадків визнання податкового боргу безнадійним деякі податкові адміні- страції мають повноваження за певних обставин переводити податкове зобов'язання з податкового боржника на третю сторону. «Наприклад, податкові адміністрації у Сполучених Штатах і Канаді можуть утримувати кошти з бізнесменів, які особисто відповідають за несплату податків, зібраних від працівників або клієнтів, як-от податок із доходів фізичних осіб (РАYЕ), внески на соціальне забезпечення та ПДВ. Зазвичай це поширюється на податки, які були зібрані на користь цільових фондів. Аналогічно деякі податкові адміністрації можуть перераховувати податковий борг особі (особі, що отримує кошти), яка має відносини «поза межами руки» (наприклад, родич) із податковим боржником, якщо одержувач отримує майно від податкового боржника за меншою від справедливої ринкової вартістю або з наміром уникнути стягнення податку» [8, с. 165].

Відповідно до практики податкового адміністрування в Італії декілька органів наділені компетенцією вживати заходів щодо стягнення податкового боргу. Особливу увагу необхідно приділити Equitalia як відокремленому департаменту Міністерства фінансів Італії.

“Equitalia - фіскально-адміністративний орган, наділений функціями і правами щодо захисту фіскальних інтересів держави. За своїм статусом неприбутковий державний холдинг з акціонерним капіталом 150 млн євро. Структурно Equitalia об'єднує 37 приватних компаній, які спеціалізуються на стягненні прострочених податкових боргів на договірних умовах і за 31 списками, переданими їй податковим відомством. Тим самим на Equitalia поширюються прерогативи, традиційно властиві лише податковій службі, з тією різницею, що Equitalia надає послуги тільки податковим органам. Останні, крім власне сум податкового боргу, штрафу і пені, сплачують на користь Equitalia комісійний збір. У разі виникнення податкового боргу Equitalia має право описати майно неплатника і виставити його на аукціон, а також визнати його безнадійним та списати у визначеному порядку» [9, с. 30-31].

Податковим кодексом Туркменістану передбачено, що «суми заборгованостей за податками, фінансовими санкціями та пенею в окремих випадках можуть бути списані за рішенням Президента Туркменістану» [10]. Закріплення такого положення $\epsilon$ цілком обґрунтованим, оскільки безнадійність податкового боргу $є$ значною загальнодержавною проблемою країни, яка потребує належного контролю й ефективного механізму вирішення. У такому разі облік подат- 
кового боргу додатково контролюється Президентом країни, що дозволяє повноцінно оцінити суми податкових боргів, які можуть бути повернені до держбюджету, а які необхідно визнати безнадійними та списати.

Висновки. У результаті проведеного аналізу окремих аспектів правового регулювання стягнення податкової заборгованості в закордонних країнах необхідно зазначити, що більшість фінансово-правових норм мають здебільшого аналогічний зміст щодо норм національного законодавства, що відображають сутність основних податкових інститутів. Однак податкова політика іноземних країн спрямована не тільки на вдосконалення механізму стягнення податкового боргу, а також на забезпечення організації та реалізації заходів запобігання податковому боргу, особливості яких необхідно враховувати і на національному рівні.

\section{Література}

1. Податковий кодекс України : Закон від 2 грудня 2010 р. № 2755-VI. URL: https://zakon. rada.gov.ua/laws/show/2755-17 (дата звернення: 15.10.2020).

2. Цвірюк Д.В. Окремі аспекти стягнення податкового боргу територіальними органами Державної фіскальної служби України. Часопис Академії адвокатури України. 2016. Т. 9. № 1. С. 29-37.

3. Про внесення змін до Податкового кодексу України щодо вдосконалення адміністрування податків, усунення технічних та логічних неузгодженостей у податковому законодавстві : Закон України від 16 січня 2020 р. № 466-IX. URL: https://zakon.rada.gov.ua/laws/show/466-20\#Text (дата звернення: 20.10.2020).

4. Олійник А.Р. Податкова застава та забезпечення виконання податкового зобов'язання : порівняльна характеристика законодавства України та Республіки Грузія. Правничий часопис Донецького університету. 2013. № 2. С. 180-186.
5. Олійник А.Р. Правова природа податкової застави в Україні та застави Азербайджанської Республіки як способів забезпечення виконання податкового обов'язку. Право і безпека. 2012. № 4. С. 80-84.

6. Процедури стягнення податкового боргу у Франції. Офіційний портал ДФС. URL: http:// sfs.gov.ua/media-tsentr/novini/print-54867.html (дата звернення: 23.10.2020).

7. Податковий кодекс Республіки Молдови : Закон від 24 квітня 1997 р. № 1163-XIII. URL: http: / / lex.md/fisc/codfiscaltxtru.htm\#Статья\%20 177 (дата звернення: 24.10.2020).

8. Трубіна М.В. Списання безнадійного податкового боргу : зарубіжний досвід. Протидія мінімізації сплати податків : світовий досвід та практика України : збірник матеріалів II Науково-практичного круглого столу, м. Ірпінь, 16-17 травня 2019 р. Київ : Алерта, 2019. С. 164-168.

9. Серебрянський Д.М., Смірнова О.М., Стадник М.В. Вплив структури фіскального відомства на організацію податкового контролю : зарубіжний досвід. Ірпінь : НДІ фінансового права, 2014. 56 c.

10. Мороз Я. Зарубіжний досвід стягнення податкової заборгованості. URL: http://www. visnuk.com.ua/ua/pubs/id/7020 (дата звернення: 28.10.2020)

Лихолат Я. А., студентка Навчально-наукового інституту права Університету державної фіскальної служби України

Мацелик Т. О., доктор юридичних наук, професор, професор кафедри фінансового права Навчально-наукового інституту права Університету державної фіскальної служби України 